\title{
The wider significance of the ANU Historical Journal
}

\author{
Jill Waterhouse
}

ANUHJ Contributor, 1977

The ANU Historical Journal ( $A N U H J$ ) was a flag hoisted at an immensely significant time in the development of the university. In the 1960s, undergraduate and Master of Arts courses were added to what had been a research-only institution - until then, student intake had been mainly confined to candidates for the Doctor of Philosophy. Key players who were to establish the $A N U H J$, together with the first of the modern buildings erected for the new academic departments, arrived with the full cohort of undergraduate and Masters students. The transformation of The Australian National University (ANU) was the result of the amalgamation of the older Canberra University College (CUC), an offshoot of the University of Melbourne, with the newer ANU. The Chairman of the CUC, Dr BT Dickson, put it this way:

The College, conceived in 1928, mothered for 30 years by the University of Melbourne, is expected to consummate a marriage with the Australian National University in the latter part of $1960 .^{1}$

In preparation for the marriage, construction began on what was initially called the CUC Arts building. Designed to house several new departments, including the new History Department, the first lectures and tutorials were held there on Monday 4 July 1960. On Wednesday 14 September 1960, the Governor-General, Lord Dunrossil, presided over the official opening, renaming the building the Haydon-Allen Building and testing the seating in the separate circular lecture theatre, popularly known as 'The Tank'.

\footnotetext{
1 'Last Degrees Ceremony at University College', Canberra Times, 1 April 1960, 3. Canberra University College (CUC) is sometimes confused with the later University of Canberra (1990), formerly the Canberra College of Advanced Education (1967).
} 
Orientation Week 1961 marked the first full year in which undergraduate teaching in Canberra was undertaken independently of the University of Melbourne. ANU was now firmly established in two sections: the wellestablished Institute of Advanced Studies and the new School of General Studies.

Two of the founders of the ANUHJ, Ron Fraser and Alastair Davidson (whose articles appear earlier in this issue), were part of the major transfer from CUC in 1961. Alastair had publicly favoured the amalgamation, drawing attention to the prestige of ANU degrees. Ron had enrolled at the College in 1957. The two, together with Anne Kingston, soon to be married to Ron, were among the movers and shakers of the reconstituted university. In 1961, Ron was elected President of the Students' Representative Council; in the same year Alastair took over from George Martin as editor of Woroni.

Manning Clark was another transferee from CUC where he had lectured since 1949, having earlier been a member of the History Department at the University of Melbourne. Since 1940 that university had been well known for the production of the journal Historical Studies and for its student-led historical society, which, in 1961, initiated the Melbourne Historical Journal $(M H J)$.

In the same year, 1961, when the publication of Clark's History of Australia Volume 1 was imminent, the $M H J$ published an extract from an advance copy in its first issue. Students in Canberra, noting the presence of the student journal and Society at the University of Melbourne, contemplated that something similar could be established at ANU. Anne (with the distinction of having had an article published in the $M H J$ in 1963), Ron and Alastair edited the first edition of the $A N U H J$, which appeared in October 1964.

The significance of the Journal should be viewed in the wider context of ANU. Rivalry existed between the well-established History Department in the Institute of Advanced Studies and the new History Department in the School of General Studies. Academics at the Institute were expected to devote themselves to research, writing, publishing, giving professional advice and presenting the occasional guest lecture, whereas for academics in the School of General Studies, teaching came first. Yet, despite the demands of lecturing and tutoring, History Department staff produced a creditable number of publications, including those in the $A N U H J$. For students, having a history journal on site provided a great opportunity to 
step forward into the professional world of publication. Albeit in a small way, the Journal helped the History Department of the School of General Studies hold its own in what had earlier been a research-only institution.

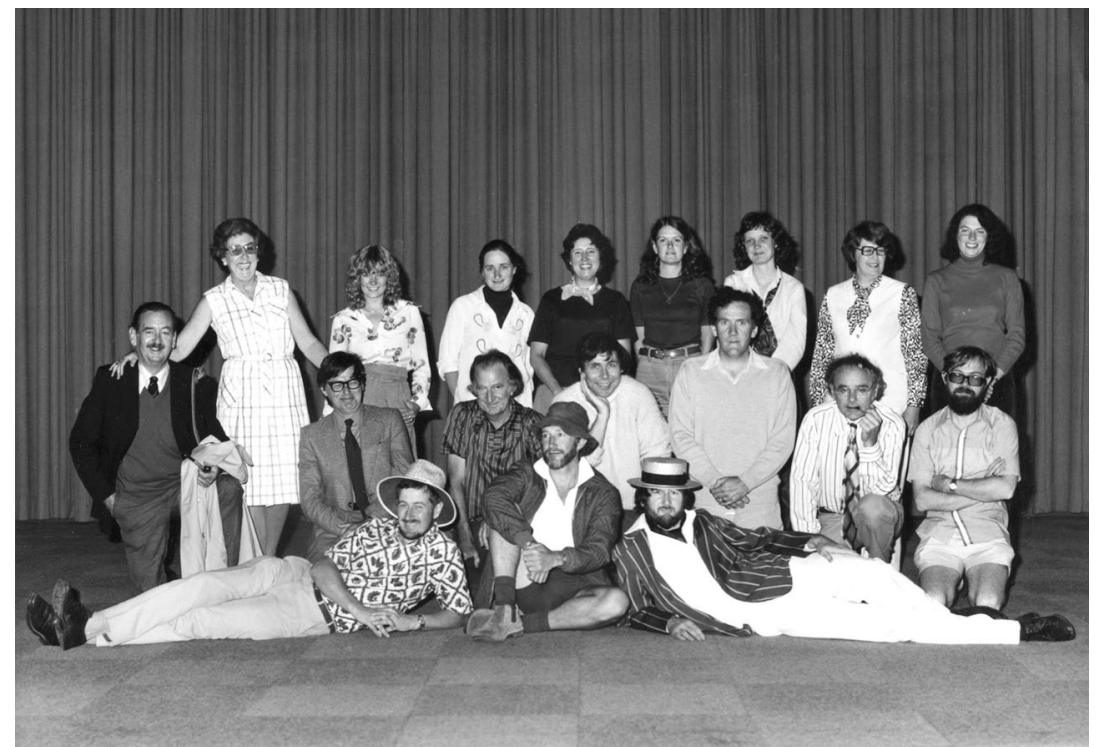

Figure 1: ANU Department of History annual photograph, 1978.

Collection: Private papers of Campbell Macknight.

The Journal helped raise the status of the History Department and the School of General Studies by encouraging cooperation among departments within the School, with the Institute, and with diplomats, public servants and other interested individuals in Canberra. It responded to a need for affirmative action to support the Arts in what was often referred to as the Age of Technology. It did not matter overmuch that the early issues of the Journal were home-made in appearance because production later improved. It was important because it announced to the wider university world that, within a very few years of its establishment, the History Department, School of General Studies, had arrived.

Even so, several of my undergraduate contemporaries say that they were unaware of the Journal's existence, being preoccupied with so much else: settling into newly built student residences, Bruce Hall (1961), Burton Hall (1965), Garran Hall (1966); studying for all-important exams; and worrying about the escalating Vietnam War, especially after the introduction of the 'birthday' ballot (1964). Students were still finding their way around the recently built General Studies Library (1964, not 
yet called the Chifley Library), and everyone had to adjust to a changing landscape after the inauguration of Lake Burley Griffin in October 1964, the same month as the appearance of the first issue of the Journal.

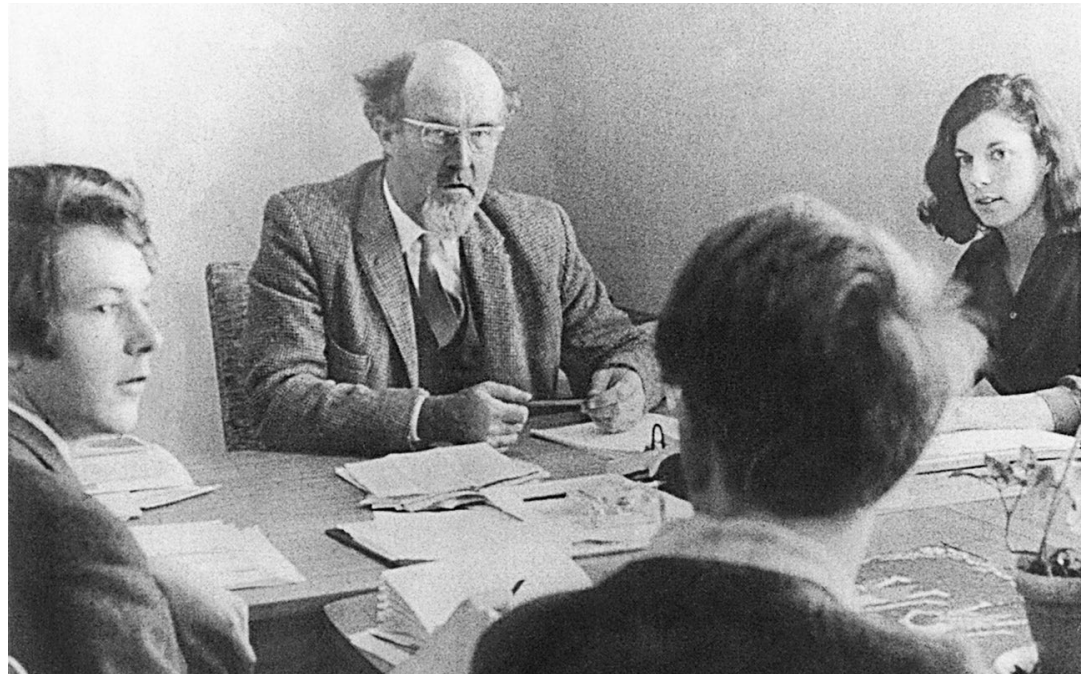

Figure 2: Manning Clark with his students Robert Moss (left) and Jill Waterhouse (right) in 1966.

Collection: Private papers of Jill Waterhouse.

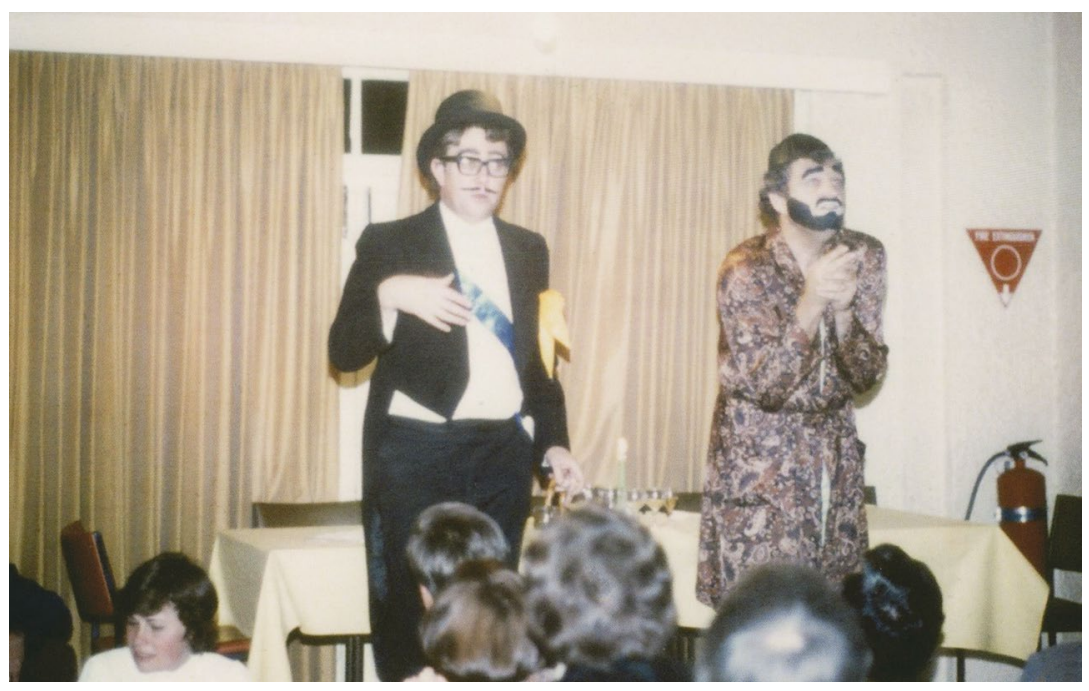

Figure 3: John Ritchie and Bill Mandle delivering a skit for a British History course, c. 1970s.

Collection: Private papers of Jill Waterhouse. 
The ANUHJ was published only intermittently in the following decades. Before the advent of photocopiers and computers, printing could be a challenge, the pressures on contributors compounded by study and exams. Even the early editions of Woroni struggled to come out on time, and so it is not surprising that the Journal failed to make a regular appearance.

I left for England in 1972 and did not contribute until 1977 when I returned as a Senior Tutor in the History Department. I entitled my review article in number 13 'A Different Jubilee: Local History in Canberra 19271977'. How parochial this must have seemed in comparison to Stephen Fitzgerald's review article of Wang Gungwu's book China and the World Since 1949: The Impact of Independence, Modernity and Revolution; Susan Jones's article on 'Kenya and the Devonshire White Paper of 1923'; Giles Short's analysis on 'Blood and Treasure: Lagos, 1851'; and Geoffrey Jukes's review article entitled 'Hitler's Generals: Ahead at Half-Time?'

Yet surely, at the national university, a study of the history of the national capital was relevant and important? I argued that on the fiftieth anniversary of the opening of 'old' Parliament House on 9 May 1977, Canberra rose in status as a subject for historical research, with landscape history and the concept of the capital city as a social laboratory being among the subjects requiring further exploration. In Australia, landscape history was an undeveloped discipline in comparison with the work in progress in Europe. Sir Keith Hancock, formerly of the Institute of Advanced Studies, had taken a firm step in the right direction with Discovering Monaro: A Study of Man's Impact on his Environment (1972). I argued that a similar study might be made of the Limestone Plains. I was pleased to note that the Australian National University Press, then directed by Brian Clouston, was promoting books about Canberra. In 1977, the Press commissioned the 'Canberra Companion' series, to which I later contributed.

While many articles in number 13 dealt with the history of other countries, Australian history was well to the fore. TB Millar, ANU Professor of International Relations, headed the publication with a study of 'Three Liberal Foreign Ministers: Spender, Casey, Menzies'. Patrick Weller from the Department of Political Science, Institute of Advanced Studies, wrote a review of Alan Powell's Patrician Democrat: The Political Life of Charles Cowper, 1843-1870. Research Fellow Robin Gollan, who with colleague Eric Fry was a founding member of the Australian Society for the Study of Labour History (1961), reviewed Blanche d'Alpuget's Mediator: A Biography of Sir Richard Kirby (1977). 
Drawing on her history honours thesis from 1973, Phillipa Weeks, by this time at the ANU Law School, contributed an article on 'John Dunmore Lang and the Colonist, 1835-1840', a subject also dear to the heart of noted lecturer Don Baker. Phillipa was to later earn a reputation as one of Australia's leading labour lawyers. She was appointed professor in 2001 and from 2000 to 2005 was Associate Dean and Head of the ANU Law School. Judith Middlebrook reviewed Geoffrey Dutton's Edward John Eyre: The Hero as Murderer (1977) and as a resident of Burgmann College (opened in 1971) she became one of Manning Clark's research assistants, pursing a distinguished career as a parliamentary officer.

Arts student Marion Roderick (later Lê) contributed her review of Black, White \& Gold: Goldmining in Papua New Guinea, 1878-1930 (1976) by Hank Nelson, one of the foremost historians of the Pacific region. Marion was on the brink of completing two degrees, an Arts degree at ANU and a Bachelor of Theology at Alliance College, Canberra. At the same time, stirred by the plight of boat people, she was active in Canberra's IndoChinese Refugee Association. JL (James) Richardson, a prolific author from the Political Science Department, reviewed Coral Bell's Diplomacy of Détente: The Kissinger Era. Reading his review again, my thoughts leapt to 2015 and the launch of the Coral Bell School of Asia and Pacific Affairs, a tribute to this distinguished analyst of international politics.

The names of those having oversight of the production of the Journal draw us further into the early history of ANU. In 1977 Gordon Murdoch Bunyan was President of the ANU Historical Society, which, as well as encouraging discussions and social events, had the responsibility for organising and circulating the Journal. PD Hurst edited number 13 and the following year was acting review editor of Australian Outlook: Journal of the Australian Institute of International Affairs, a publication advertised on the inside cover of the Journal. Committee members of the ANU Historical Society included Fiona Hamblin, Amanda Russell, HA (Harold) Aspland, Charles Maskell, Robert Lee and Peter Blanchard. Giles Short, younger son of Dr John Short, the first Warden of Garran Hall, and his wife Elizabeth, assistant to Eugene Kamenka in the History of Ideas Unit, was a student committee member.

The ANU History Department is rightly proud of the emphasis it has always placed on the use of contemporary documents and careful footnoting, as distinct from overreliance on secondary sources and slapdash attributions. Sir Paul Hasluck, a former Reader in History at the University of Western Australia and Governor-General of Australia from 
1969 to 1974 , contributed an article to number 13 entitled 'Anthologies, Archives and Other Sources'. Dismayed by the careless use of the term 'document' and by footnotes forming a smokescreen instead of confirming judgements, he advocated a much more rigorous approach to evidence. This short quotation gives the flavour of his objections (to research from some unnamed university):

In recent years it has been my melancholy fate to read three theses. [In] one of these, which swarmed with so many footnotes that reading it was like going for a hot walk in the bush-fly season, the writer had found one long and colourful piece of paper containing many unsupported allegations by an interested party. Without ever evaluating the document itself he had used it for at least a dozen separate assertions of historical fact. ${ }^{2}$

Hasluck provides several detailed examples of the questionable use of so-called evidence-for instance, the curious use made of press briefings when determining the views of prime minister John Curtin on conscription issues.

Since Hasluck's day, access to both archival and published sources has advanced in leaps and bounds, especially through the National Library of Australia's Trove and other online platforms, including the detailed work in progress on the ANU archives. Even so, his article remains relevant to the young scholar and could well be brought to the attention of today's students.

The value of the ANU Historical Journal Mark I 1964-87 is much greater than that of an archive to be dusted off only occasionally. The content remains of interest today, forming an excellent foundation for the ANU Historical Journal Mark II, 2019-onwards.

Jill Waterhouse's association with ANU has come full circle, beginning in 1963-66 when she was a history honours student. In the 1970s and 1980s she tutored in History Department, and some may remember the staff and student parties held in her grandparents' home, Calthorpes' House. After spending 13 years in Cambridge, supervising and lecturing in Modern British History, she returned to Australia in 1990 to join the staff at the new Canberra Museum and Gallery. In 2006 Jill embarked on an ANU PhD, a biography of Sir John Henry

2 Sir Paul Hasluck, 'Anthologies, Archives and Other Sources', review of Documents on Australian International Affairs 1901-1918, ed. Gordon Greenwood and Charles Grimshaw, in ANU Historical Journal 13 (1977), 57. 
ANU Historical Journal II, Number 1

Butters (1884-1969). In 2002 she contributed a chapter to Glenn Tomasetti (ed.), Manning Clark By Some of his Students and in 2004 published University House: As They Experienced It, A History 1954-2004. She continues to research aspects of ANU. 
This text is taken from ANU Historical Journal II: Number 1, published 2019 by ANU Press, The Australian National University, Canberra, Australia.

doi.org/10.22459/ANUHJII.2019.07 